\title{
Human Giant Cell Tumors of Bone Identification and Characterization of Cell Types
}

Steven R. Goldring, ${ }^{\S}$ Merrilee S. Roelke, ${ }^{\star}$ Kathleen K. Petrison, ${ }^{*}$ and Atul K. Bhan¥

Departments of ${ }^{*}$ Medicine and $\ddagger$ Pathology, Harvard Medical School; ${ }^{*}$ Medical Services (Arthritis Unit) $\ddagger$ Department of Pathology, Massachusetts General Hospital, Boston, Massachusetts 02114; and §Department of Medicine,

New England Deaconess Hospital, Boston, Massachusetts 02215

\begin{abstract}
Cells cultured from human giant cell tumors of bone were characterized on the basis of morphological features, proliferative capacity, presence of granulocyte-monocyte antigens, receptors for skeletal hormones, and soluble cell products. Three major cell types were identified. One population consisted of mononuclear cells with fibroblastic morphology, which proliferated in culture and most likely represent the neoplastic element of the tumor. Phenotypically they resembled a connective tissue stromal cell. A second population of mononuclear cells lacked receptors for skeletal hormones and did not persist in culture. These cells were likely of monocyte-macrophage lineage. A third population of cells consisted of large multinucleated giant cells. These cells possessed phenotypic features of osteoclasts including receptors for calcitonin. Human giant cell tumors of bone are most likely a neoplasm of connective tissue stromal cells, which have the capacity to recruit and interact with multinucleated giant cells that exhibit phenotypic features of osteoclasts.
\end{abstract}

\section{Introduction}

Giant cell tumors of bone are relatively uncommon tumors of skeletal tissue that produce expansile well delineated lytic lesions (1-6). These tumors are characterized by the presence of large multinucleated giant cells distributed among distinctive stromal cells. The histochemical and ultrastructural features of the tumor giant cells and the tendency of the tumors to induce osteolysis have led several authors to characterize the multinucleated cells as osteoclasts and classify the tumors as osteoclastomas (7-13). Recent evidence suggesting that the multinucleated giant cells are indeed osteoclasts has been provided by Horton et al. $(14,15)$, who developed monoclonal antibodies that react with multinucleated cells present in giant cell tumors. These authors suggested (but did not provide proof) that these antibodies recognize cellular antigens that are osteoclast-specific. Because there is considerable evidence that osteoclasts are derived from hematopoietic stem cells of monocyte-macrophage origin (16-18),

Portions of this work were presented at the Annual Meeting of the American Society of Bone and Mineral Research in Hartford, CT in June, 1984, and have been published as an abstract (1984, Calcif. Tiss. Int., 36:460). This is publication No. 1017 of the Robert W. Lovett Memorial Group for the Study of Diseases Causing Deformities.

Reprint requests should be addressed to Dr. Goldring, Arthritis Unit, Massachusetts General Hospital, Fruit Street, Boston, MA 02114.

Received for publication 23 July 1986.

J. Clin. Invest.

(c) The American Society for Clinical Investigation, Inc.

0021-9738/87/02/0483/09 \$1.00

Volume 79, February 1987, 483-491 several other investigators have examined cells (both mononuclear and multinucleated) present in giant cell tumors for the presence of la and specific granulocyte-monocyte antigens (1921). Although cells expressing monocyte-macrophage phenotype have been identified in the tumors, the precise relationship of these cells to the tumor stromal cells and multinucleated giant cells has not been definitively established.

Our present investigations were therefore undertaken to further characterize the cells present in giant cell tumors and to establish a possible relationship of these cells to other cells of skeletal and connective tissue origin. We previously showed that cells cultured from giant cell tumors increase cAMP when incubated with parathyroid hormone (PTH), ${ }^{1}$ calcitonin (CT), or prostaglandin $\mathrm{E}_{2}\left(\mathrm{PGE}_{2}\right)(21-27)$. These studies did not permit identification of the individual hormone-responsive cell populations, however. In the present studies we used an autoradiographic technique that enabled us to examine cells cultured from these tumors for the presence of receptors for CT, a hormone believed to act directly on osteoclasts through specific cell surface receptors. The presence of receptors for $C T$ is regarded as a distinctive marker of osteoclast phenotype because other skeletal tissue cells lack receptors for this hormone. In addition, we examined the capacity of cells cultured from these tumors to synthesize and secrete collagen and other high molecular weight proteins. Based on our observations, we conclude that giant cell tumors of bone are neoplasms of connective tissue stromal cells, which may have the unique capacity to recruit or interact with multinucleated giant cells possessing receptors for CT and exhibiting other phenotypic features of osteoclasts.

\section{Methods}

Tissue preparation and culture procedures. Specimens of tissue from giant cell tumors of bone were obtained at the time of surgery from patients undergoing tumor resection and were kindly provided by Drs. Henry J. Mankin and Mark C. Gebhardt (Orthopaedic Service, Massachusetts General Hospital). Tissues were prepared for culture by dispersion with trypsin-EDTA and clostridial collagenase and cultured in Dulbecco's modified Eagle's medium (DMEM) (Gibco, Grand Island, NY) plus $10 \%$ fetal calf serum (FCS) (Bioproducts, Inc., Warrenton, OR) and penicillin $100 \mathrm{U} / \mathrm{ml}$ and streptomycin $100 \mu \mathrm{g} / \mathrm{ml}$ (Gibco) as previously described $(22,23)$. Tissue samples for what we call fragment culture were cut into small fragments $2-3 \mathrm{~mm}$ /diameter and placed in 6-cm-diameter tissue culture dishes (Falcon Labware, Becton, Dickinson \& Co., Oxnard, CA). The fragments were teased apart and covered with a drop of culture medium (DMEM, 10\% FCS). After $24 \mathrm{~h}, 2 \mathrm{ml}$ of fresh medium were added and medium changed at 5-7-d intervals.

Hormone incubation. Measurement of the acute cAMP response to

1. Abbreviations used in this paper: CT, calcitonin; DMEM, Dulbecco's modified Eagle's medium; $\mathrm{PGE}_{2}$, prostaglandin $\mathrm{E}_{2} ; \mathrm{PTH}$, parathyroid hormone. 

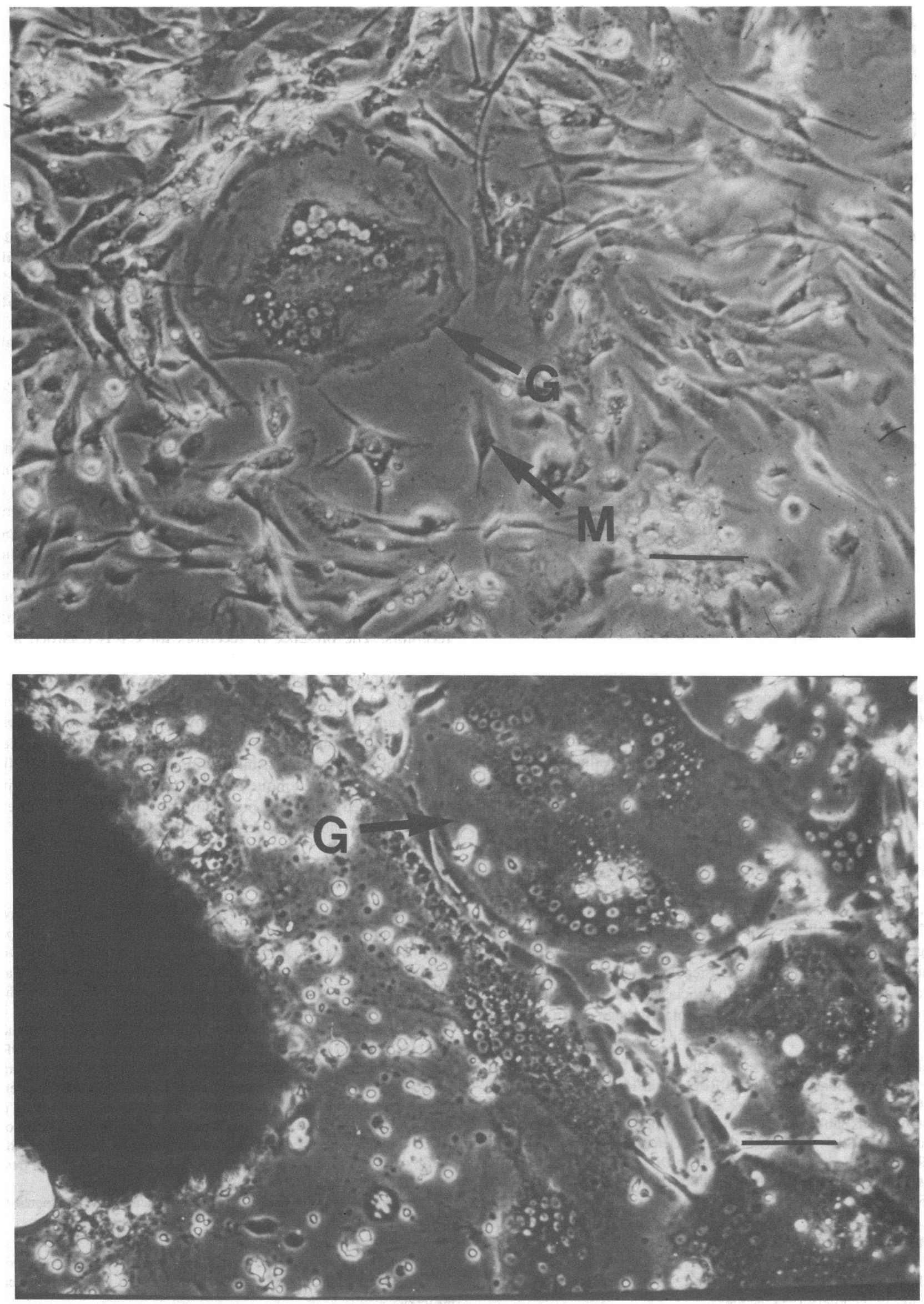
hormones was performed on cells in plastic trays containing 24 individual wells (Costar, Data Packaging Corp., Cambridge, MA). To study cells in primary culture, after dispersion from tumor tissue, cells were plated at $2 \times 10^{5}$ cells/well. The nonadherent cells were removed after $24 \mathrm{~h}$ and the adherent cells cultured in DMEM, $10 \%$ FCS for 3-5 d. To evaluate cAMP responses in passaged cells, $48 \mathrm{~h}$ before incubation with hormone, cells were trypsinized and plated at a density of $5 \times 10^{4}$ cells/well in $24-$ well trays. Immediately before the test incubation, medium was removed and replaced with test buffer solution (Dulbecco's phosphate-buffered saline [PBS] supplemented with $0.9 \mathrm{mM}$ calcium, $0.5 \mathrm{mM}$ magnesium, $0.25 \%$ bovine serum albumin [Pentex, Miles Laboratories, Kankakee, IL], $1 \mathrm{mM}$ 3-isobutyl-1-methyl xanthine [Aldrich Chemical Co., Milwaukee, WI], and $0.1 \%$ glucose) containing the appropriate hormone. The trays were incubated at $37^{\circ} \mathrm{C}$ for $20 \mathrm{~min}$ after which they were placed in a water bath at $100^{\circ} \mathrm{C}$ and brought to dryness. To assay for cAMP, the cells were resuspended in CAMP assay buffer, the wells scraped, the cells pelleted by centrifugation at $500 \mathrm{~g}$ for $10 \mathrm{~min}$, and the supernate assayed for cAMP content. A ${ }^{125}$ I-cAMP radioimmunoassay kit (BectonDickinson \& Co., Paramus, NJ) was used for assay according to the procedures previously described $(22,23)$.

Analysis of cell surface markers. Cells obtained from the tumors by proteolytic dispersion or cells previously established in culture were plated in four-chamber Lab-tek slides (Miles Laboratories, Inc., Naperville, IL). Before testing, washed cells were incubated with heat-aggregated and monomeric human IgG (1:1 ratio, $25 \mathrm{mg} / \mathrm{ml}$ in PBS) for $45 \mathrm{~min}$ to block nonspecific binding of the monoclonal antibodies to $\mathrm{Fc}$ receptors. Cells were then incubated with each monoclonal antibody for $30 \mathrm{~min}$ and the presence of specific antigens assayed using an avidin-biotin immunoperoxidase technique (28). The following monoclonal antibodies were used: OKT8, OKM1, OKIa (Ortho Pharmaceutical Corp., Raritan, NJ), anti-leu-4, anti-HLA-DR, anti-leu M3, anti Leu 10 (DC/DS) now designated DQ (Becton-Dickinson \& Co., Mountain View, CA), and antiT4, (Coulter clone; Coulter Electronics, Hilaleah, FL [28]). Tissue for frozen-section immunohistology was snap frozen in OCT embedding compound (Ames Co., Miles Laboratories, Inc., Elkhart, IN) and stored in liquid nitrogen. Frozen sections $(4 \mu \mathrm{m})$ were fixed in dry acetone for $10 \mathrm{~min}$, dried, and prepared for screening for specific antigens in a manner similar to cell cultures (28).

CT autoradiography. Salmon CT was iodinated by the chloramineT method (29) and the $\left[{ }^{125} \mathrm{I}\right] \mathrm{salmon} \mathrm{CT}(100 \mathrm{Ci} / \mathrm{mmol})$ charged onto a column $(0.5 \times 35 \mathrm{~cm})$ of Sephadex G-25 (superfine) equilibrated with $0.01 \mathrm{M}$ acetic acid. The column was eluted with $0.01 \mathrm{M}$ acetic acid $/ 0.1 \%$ albumin (wt/vol) and 1.0-ml fractions collected. Cells studied included the LLC-PK 1 strain, prepared from porcine kidney as described by Hull (30), dermal fibroblasts, and cells cultured from giant cell tumor tissue. Cells were incubated at $37^{\circ} \mathrm{C}$ in Lab-tek chambers or $3.5-\mathrm{cm}$ dishes with $\left[{ }^{125} \mathrm{I}\right] \mathrm{salmon} \mathrm{CT}\left(5 \times 10^{4} \mathrm{cpm} / \mathrm{ml}\right)$ in the presence or absence of unlabeled salmon CT. After 20-360 min, medium was removed, cells washed four times with PBS, and fixed in 10\% formaldehyde followed by dehydration with sequential washes in ethyl alcohol. In the dark, fixed cells were coated with NTBII emulsion (Eastman Kodak Co., Rochester, NY) and stored at $4^{\circ} \mathrm{C}$ for 2-3 wk. Plates or slides were developed in Dektol (Eastman Kodak Co.) for 6 min and cells stained with Giemsa.

Characterization of medium proteins. Cells were plated at $2 \times 10^{5}$ cells/dish in $3.5-\mathrm{cm}$ dishes and collagen synthesis assayed by methods previously described (28). After $2 \mathrm{~d}$ they were incubated in DMEM without serum for $24 \mathrm{~h}$ with $25 \mu \mathrm{Ci}$ of $\mathrm{L}-\left[5-{ }^{3} \mathrm{H}\right]$ proline $(30 \mathrm{Ci} / \mathrm{mmol}$, Amersham-Searle Corp., Arlington Heights, IL) in the presence of $50 \mu \mathrm{g} / \mathrm{ml}$ $\beta$-aminopropionitrile, $50 \mu \mathrm{g} / \mathrm{ml}$ ascorbic acid, and $2 \mathrm{mM}$ glutamine. Medium proteins were analyzed by SDS polyacrylamide gel electrophoresis (PAGE) (5\% acrylamide) with or without reduction with $0.5 \% \beta$ mercaptoethanol. ${ }^{14} \mathrm{C}$-labeled rat tail tendon collagen was used as a molecular weight marker. The labeled collagen in the medium was further characterized after pepsinization at $4^{\circ} \mathrm{C}$ and the collagens analyzed by SDS PAGE with delayed reduction to distinguish $\alpha 1$ (I) from $\alpha 1$ (III) chains. Fluorograms of the gels were prepared as described (31).

\section{Results}

Morphology of cells cultured from giant cell tumors of bone. Fig. 1 (Top) shows the appearance of adherent cells in primary culture after dispersion from tumor tissue. Cells included large multinucleated giant cells and a heterogeneous population of mononuclear cells, some of which were fibroblast-like and others rounded cells with morphological features of monocyte-macrophages. With time in culture, the large multinucleated cells disappeared, and after 2-3 wk the predominant cell type was a fibroblast-like cell with a rounded epithelioid appearance. Occasionally cells with up to two to three nuclei were seen, but the large multinucleated cells (>10 nuclei/cell) were no longer detected. Treatment with hormones (1,25-dihydroxyvitamin $\mathrm{D}_{3}$, PTH, salmon CT, or $\mathrm{PGE}_{2}$ ) did not affect the survival of the multinucleated giant cells. Increasing the concentration of FCS or substitution with autologous or heterologous human sera prolonged the survival of multinucleated cells (data not shown), but did not prevent their eventual loss from culture. After second passage only the fibroblast-like cells were detected.

Fig. 1 (Bottom) shows the appearance of outgrowth cells from tissue fragments cultured from a giant cell tumor. As in the cultures of dispersed cells, the outgrowth cells were heterogeneous, and included large multinucleated giant cells and a heterogeneous population of mononuclear cells. In contrast to cultures of dispersed cells, giant cells continued to appear in fragment culture even after several months. Serial observations suggested that the large multinucleated cells migrated from the margins of the tumor fragments. At no time did multinucleated cells appear to form in situ at sites removed from tissue fragments. Removal of tumor tissue from the culture plates resulted in disappearance of the giant cells, whereas when these tissue fragments were added to new plates the multinucleated cells appeared within 1-2 wk.

Analysis of cell-associated antigens. We previously showed that some cells present in primary cultures of giant cell tumors of bone demonstrate phenotypic features of monocyte-macrophages $(21-23,32)$. To further characterize cells present in giant cell tumors, intact tissue sections and cells cultured from giant cell tumors were reacted with monoclonal antibodies, which recognize antigens associated with mononuclear and connective tissue cells. Table I shows the distribution of cell surface antigens in frozen sections from operative specimens and in cells in primary cultures from three giant cell tumors. In all tumors from 10 to $40 \%$ of the mononuclear cells in primary culture expressed cellular antigens associated with a monocyte-macrophage phenotype. By second passage, only rare $(<5 \%)$ cells expressed monocyte-macrophage antigens, suggesting that the cells, which proliferated in culture and likely represent the neoplastic element, were not of monocyte-macrophage lineage. Although up to 5\% of the multinucleated giant cells reacted positively with anti-DR or DQ monoclonal antibodies (BDIa and Leu 10 respectively), most did not. Antigens characteristic of monocyte-macrophages were not detected on the giant cells. Results in tumor sections 
Table I. Characterization of Mononuclear Cell-associated Antigens in Tissue Sections and in Primary Cultures of Cells Cultured from Giant Cell Tumors of Bone

\begin{tabular}{lcc}
\hline & \multicolumn{2}{l}{$\begin{array}{l}\text { Mononuclear cell binding } \\
\text { of monoclonal antibody }\end{array}$} \\
\cline { 2 - 3 } Monoclonal antibody & Tissue section & Cell culture \\
\hline & $\%$ & $\%$ \\
T8 & $2.3 \pm 1.4$ & - \\
Leu 4 & $1.7 \pm 1.7$ & 0 \\
Leu 10 (DQ) & $31.7 \pm 10.1$ & $6.7 \pm 1.4$ \\
BDIa & $43.3 \pm 6.7$ & $23.3 \pm 7.2$ \\
OKM1 & $11.7 \pm 7.3$ & $6.7 \pm 1.4$ \\
Leu M3 & $11.7 \pm 3.3$ & $9.0 \pm 4.5$ \\
T6 & $6.7 \pm 4.4$ & 0 \\
\hline
\end{tabular}

Cells in primary culture and frozen sections from tissue from three giant cell tumors of bone (GT-42, 43, 47) were examined for the presence of surface antigens by incubating samples with monoclonal antibodies that recognize antigens associated with T cells (T8, Leu 4), granulocyte-monocytes (Leu M3, OKM1), Langerhans giant cells (T6), or Ia antigens (BDIa, Leu $10 \mathrm{DQ}$ ). Antigen-positive cells were identified by avidin-biotin immunoperoxidase staining. Values represent mean \pm SEM, $n=3$.

were similar but not identical to those obtained with the dispersed cells. As in the cultured cells, a small percentage of the giant cells were reactive with the Leu 10 reagent, which recognizes the DQ antigen(s). The mononuclear cell population showed variable but consistent reactivity with the monoclonal antibodies with specificity for monocyte-macrophages. In tumor sections, unlike the dispersed cells, a small percentage of cells reacted with reagents that recognized $\mathrm{T}$ lymphocyte antigens. Because $T$ lymphocytes do not usually adhere to tissue culture surfaces and because culture conditions do not favor $T$ cell growth, cells with this phenotype may have been lost during culture.

Hormone-induced cAMP responses. We previously showed that cells dispersed from giant cell tumors and studied after passage increase cAMP levels when tested with PTH or $\mathrm{PGE}_{2}$ but not with CT $(21-23,32)$. Because multinucleated cells as well as some of the mononuclear cell types appeared to be lost with time in culture or after passage, cells were examined in primary culture within 5-7 d after dispersal from tumor tissue. Table II shows the pattern of cAMP responses to hormones in cells from one tumor in primary culture and after passage. Although CT

Table II. Effects of Age in Culture on Hormone-induced cAMP Responses in Cells Cultured from a Giant Cell Tumor of Bone

\begin{tabular}{lllll}
\hline & \multicolumn{3}{l}{ Test incubation cAMP } & \\
\cline { 2 - 5 } & Buffer & PTH & PGE $_{2}$ & CT \\
\hline & pmol/well & pmol/well & pmol/well & pmol/well \\
& & & & \\
Primary culture & $1.7 \pm 0.4^{*}$ & $34.1 \pm 2.1$ & $39.2 \pm 1.2$ & $4.6 \pm 0.7$ \\
Passage 1 & $0.7 \pm 0.2$ & $24.0 \pm 1.2$ & $28.5 \pm 1.0$ & $0.5 \pm 0.1$ \\
\end{tabular}

Cells were incubated for $20 \mathrm{~min}$ at $37^{\circ} \mathrm{C}$ in buffer containing 3-isobutyl-1-methyl xanthine $(1 \mathrm{mM})$ alone or with added PTH $\left(10^{-7} \mathrm{M}\right)$, $\mathrm{PGE}_{2}\left(3 \times 10^{6} \mathrm{M}\right)$, or salmon CT $\left(3 \times 10^{-7} \mathrm{M}\right)$.

$*$ Values represent mean $\pm \mathrm{SEM}, n=3$. responses were detected in cells in primary culture, such responses were not detected in cells tested after one passage.

$\left[{ }^{125} I\right]$ salmon $C T$ autoradiography. To identify the individual CT-responsive cells in primary cultures, an autoradiographic technique using $\left[{ }^{125} \mathrm{I}\right]$ salmon $\mathrm{CT}$ was developed. The technique was validated and quantitated using the LLC-PK ${ }_{1}$ renal tubular cells, which had previously been found to possess specific cell surface receptors for CT (33). Fig. 2 shows an autoradiograph of the LLC-PK ${ }_{1}$ cells and dermal fibroblasts after incubation with [ $\left.{ }^{125} \mathrm{I}\right]$ salmon $\mathrm{CT}$. The dermal and renal cells were easily distinguished on the basis of morphologic features. Only the renal tubular epithelial cells demonstrated CT binding. Addition of unlabeled CT to cells incubated with $\left[{ }^{125} \mathrm{I}\right]$ salmon CT resulted in loss of CT binding.

To further establish the validity and specificity of the autoradiographic technique the following protocol was designed. LLC-PK ${ }_{1}$ renal tubular cells were passaged into $2.5-\mathrm{cm}$ culture dishes at a density of $2.5 \times 10^{5}$ cells/plate. After $48 \mathrm{~h}$ cells were incubated with $\left[{ }^{125} \mathrm{I}\right]$ salmon $\mathrm{CT}$ in the presence or increasing concentrations of unlabeled salmon CT. Cells were prepared for autoradiography and the plates scanned with a soft laser scanning densitometer (model SL-504 $\times$ L; Biomed Instruments Inc., Fullerton, CA). Relative densities were analyzed with a Zeineh Videophoresis 11.PC program (Biomed Instruments Inc.; data not shown). The addition of increasing concentrations of unlabeled salmon CT resulted in a dose-dependent decrease in the density of granules, reflecting the displacement of $\left[{ }^{125} \mathrm{I}\right]$ salmon CT. Concentrations of unlabeled salmon CT as low as $10^{-9} \mathrm{M}$ produced a reduction in granule density. Maximal displacement occurred with $10^{-6} \mathrm{M}$ salmon CT. These results are comparable to those obtained in binding studies with renal membranes or in intact cells. Recently Nicholson et al. (34) have used a similar technique to examine osteoclasts isolated from rodent long bone for the presence of CT receptors. As in our studies, the osteoclast type giant cells specifically bound CT, consistent with the presence of receptors for this hormone. We have obtained similar results with isolated rodent osteoclasts (data not shown).

Using the autoradiographic technique, we studied primary and passaged cells from five tumors, which include outgrowth multinucleated and mononuclear cells from fragment cultures. Fig. 3 is an autoradiograph of cells from one giant cell tumor in primary culture. Most ( $>90 \%)$, but not all of the multinucleated giant cells in primary culture bound $\left[{ }^{125} \mathrm{I}\right]$ salmon $\mathrm{CT}$. Occasional mononuclear cells also bound CT. After passage no CT binding was demonstrable. In parallel studies, cells after passage did not increase cAMP levels when test-incubated with CT.

To further quantitate $\left[{ }^{125} \mathrm{I}\right]$ salmon $\mathrm{CT}$ binding in multinucleated cells, autoradiographs from primary cultures of four giant cell tumors were photographed and $35-\mathrm{mm}$ slides projected onto a gridwork with $2 \times 2$-cm squares. Each square represented 100 $\mu \mathrm{m}^{2}$. Granules $/ 100 \mu \mathrm{m}^{2}$ were counted in regions devoid of cells (background) and over the cytoplasm of multinucleated cells. The density of granules over multinucleated cells was significantly greater than background in all cultures studied (Table III). Because granule density varied in individual giant cells and because some cells failed to demonstrate CT binding, it was not possible to quantitate CT receptor number or binding affinity.

Matrix proteins synthesized by stromal cells. To establish the relationship of cells present in giant cell tumors to other connective tissue or hematopoietic cells, we examined the high molecular weight secreted proteins synthesized by cells cultured from giant cell tumors. We speculated that the matrix compo- 


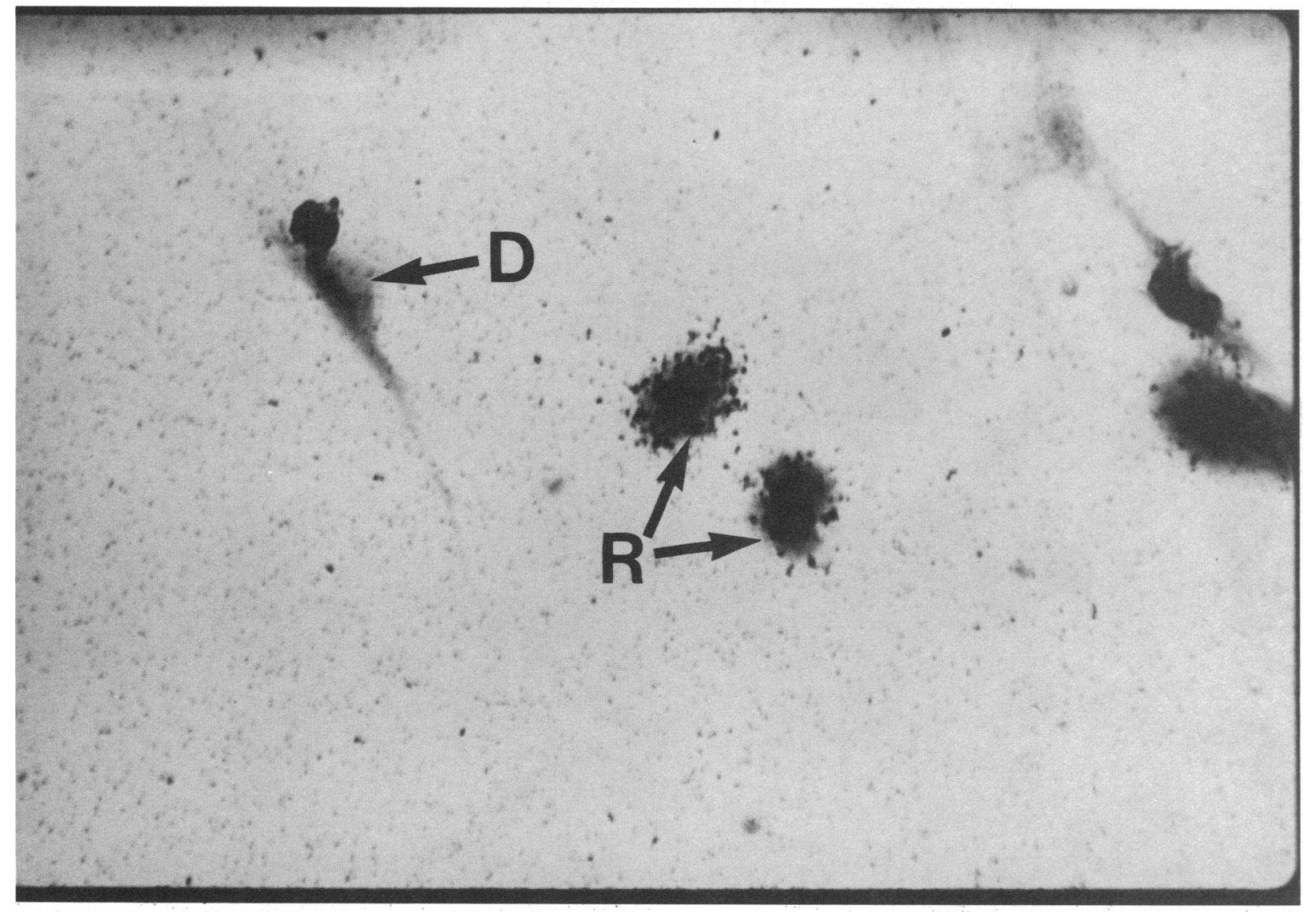

Figure 2. CT binding to cultured cells demonstrated by radioautography. Renal tubular cells (LLC-PK $)_{1}$ ) and human dermal fibroblasts were incubated for $3 \mathrm{~h}$ with $\left.{ }^{125} \mathrm{I}\right]$ salmon $\mathrm{CT}$. After fixation and dehydration cells were coated with photographic emulsion, stored for 2-3 wk at $4^{\circ} \mathrm{C}$ and $\mathrm{CT}$ binding demonstrated by autoradiography. Binding can be observed in the renal tubular cells $(R)$ but not in the dermal fibroblasts $(D)$ by the presence of silver grains overlying the cells. nents synthesized by these cells might to some extent serve as phenotypic markers for establishing the relationship of tumor cells to specific connective tissue cells. Only passaged cells were examined, because it is likely that the cells that proliferated in culture and persisted after passage represented the neoplastic element of the tumor. Fig. 4 shows the patterns of labeled medium proteins under reducing and nonreducing conditions. Several different proteins, including products with mobility characteristic of fibronectin, and fully and partially processed types I and III procollagen were identified. The pattern of collagen types in cells cultured from six different giant cell tumors were qualitatively similar. Although the pattern resembled that seen in dermal fibroblasts, several lower molecular weight species were present, suggesting extensive processing of the procollagens. Pepsinization and delayed reduction permitted identification of the alpha 1(I) and the alpha 1(III) collagen chains and established the presence of both types I and III collagen in the medium proteins (Fig. 5). The ratios of Type I and III collagen were assessed by densitometric scanning of the fluorograms. Ratios of $\alpha 1$ (I) $+\alpha 2(\mathrm{I}) / \alpha 1$ (III) ranged from 14.1 to 30.3 .

\section{Discussion}

In previous studies we showed that a heterogeneous population of cells could be cultured from human giant cell tumors of bone, and that the cells in early primary culture exhibited phenotypic features of cells present in the original tumor $(21-23,31)$. Primary cultures contained many large multinucleated giant cells and a mixed population of mononuclear cells, many of which expressed functional characteristics of monocyte macrophages, including synthesis of lysozyme, presence of surface immunoglobulin Fc receptors, and ability to phagocytose India ink particles. Wood et al. (35) reported similar results, noting that 11$40 \%$ of cells dispersed from giant cell tumors possessed macrophage markers ( $\mathrm{Fc}$ and $\mathrm{C} 3$ receptors).

The availability of monoclonal antibodies that recognize cellular antigens associated with specific mononuclear cell types has helped to more firmly establish the identity of cells present in giant cell tumors. Using these reagents we found that $10-40 \%$ of the mononuclear cells present in primary cultures of cells dispersed from giant cell tumors expressed antigens associated with monocyte-macrophages. Examination of tissue sections before proteolytic dispersion yielded roughly comparable results. However, cells expressing $\mathrm{T}$ cell-associated antigens that were detected in tissue sections, were not present in cell cultures. This is not surprising because conditions used for these cultures did not favor $T$ cell adherence or proliferation. The presence of $T$ cell infiltration is characteristic of many neoplasms and thus is not a finding unique for giant cell tumors (36).

Our results are similar to those reported by Burmester et al. (20), who also described the presence in primary cultures of giant cell tumors of cells expressing monocyte-macrophage an- 


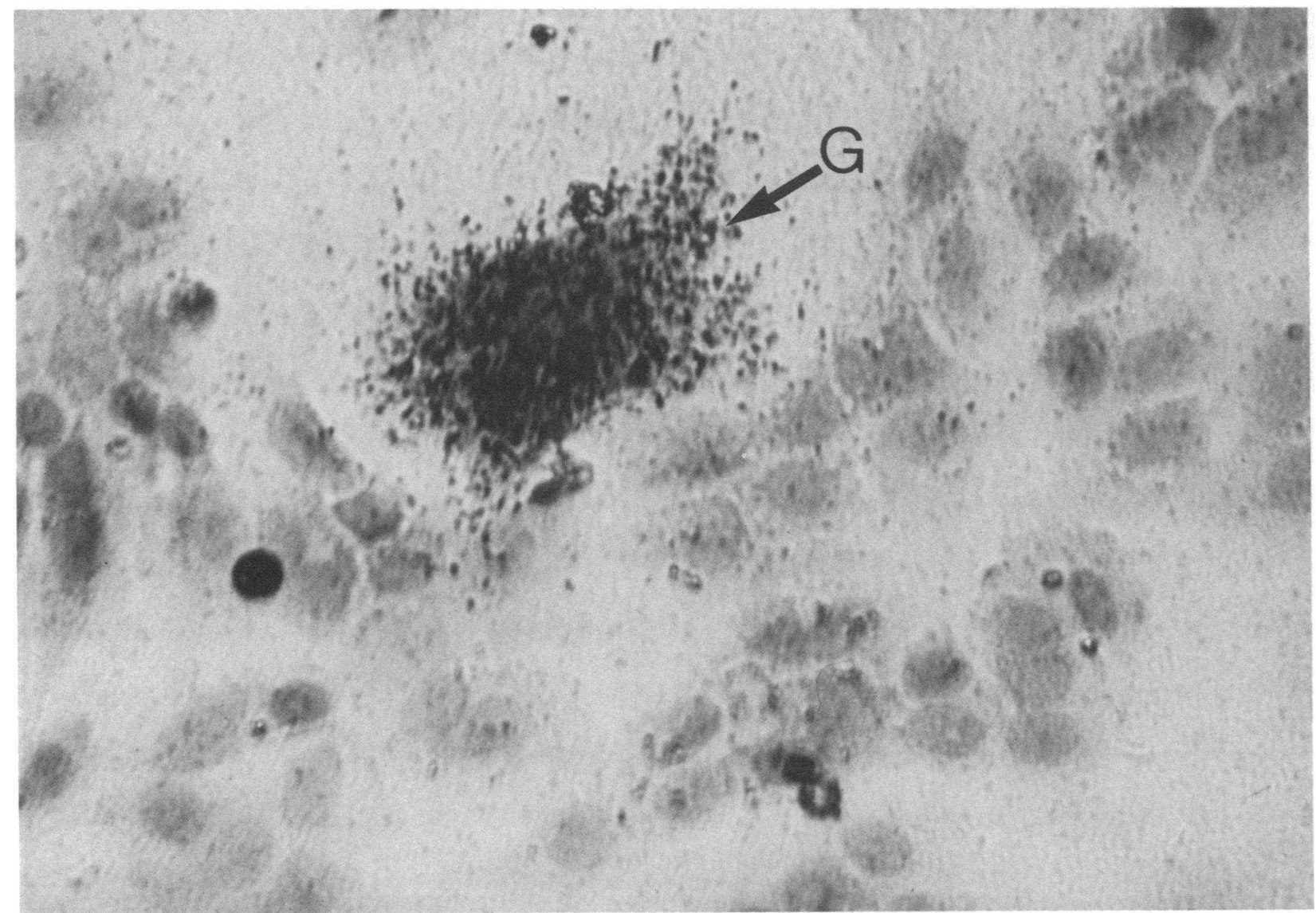

Figure 3. CT binding to giant cell tumor cells. Cells from primary culture from a giant cell tumor (GT-47) were incubated for $3 \mathrm{~h}$ with $\left[{ }^{125} I\right]$ salmon CT. Specific CT binding to a giant cell $(G)$ is shown by the presence of silver grains over the cell.

tigens. These authors noted that these mononuclear cells differed from mature tissue macrophages by their relatively limited phagocytic activity, the presence of an antigen characteristic of early monocytoid cells, and the absence of a single antigen associated with peripheral blood and tissue macrophages. They suggested that this cell type might be derived from a hematopoietic progenitor related to the mononuclear phagocyte, but

Table III. Quantitative CT Binding in Multinucleated Giant Cells Cultured from Giant Cell Tumors of Bone

\begin{tabular}{llc}
\hline Tumor & Over giant cells & Not over giant cells \\
\hline & Grains $/ 100^{2}$ & Grains $/ 100^{2}$ \\
GT-42 & $23.3 \pm 4.3^{*}$ & $9.8 \pm 3.3$ \\
GT-47 & $38.3 \pm 4.5$ & $14.3 \pm 0.4$ \\
GT-48 & $23.8 \pm 2.3$ & $6.5 \pm 1.8$ \\
GT-50 & $61.5 \pm 12.6$ & $2.5 \pm 1.1$ \\
\hline
\end{tabular}

Cells from four giant cell tumors were incubated with [ $\left.{ }^{125} \mathrm{I}\right]$ salmon CT and autoradiographs prepared. To establish significance of CT binding, the number of grains per $100 \mu^{2}$ were counted and compared with the number of grains per unit area over mononuclear cells or areas devoid of cells. The grain density over giant cells was significantly greater than background $(P<0.005)$ in all cell cultures.

* Each value represents the mean counts for three squares and SD, $n=3$. representing a cell developing along a pathway distinct from that of monocytes or macrophages. They also described a population of mononuclear cells that were $\mathrm{Ia}^{+}$but failed to express monocyte-macrophage-associated antigens. They speculated that endothelial cells might account for this population. Alternatively, the patterns of reactivity in the mononuclear cells could reflect the influence of local conditions or factors present within

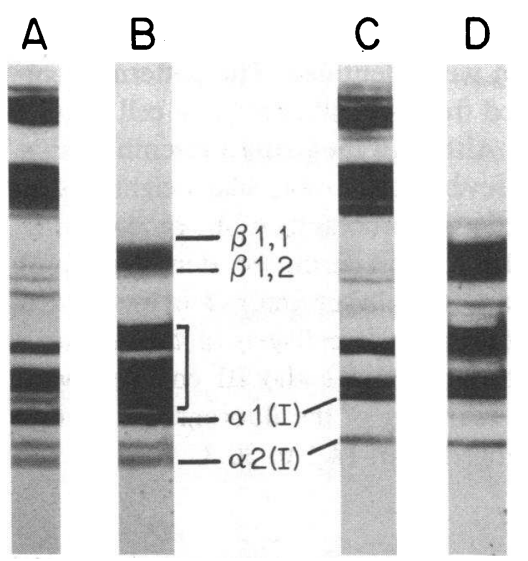

Figure 4. Medium proteins synthesized by cultured cells. Stromal cells cultured from a giant cell tumor (lanes $A$ and $B$ ) or adult human dermis (lanes $C$ and $D$ ) were incubated with $\left[{ }^{3} \mathrm{H}\right]$ proline and the medium proteins characterized by SDS PAGE without (lanes $A$ and $C$ ) or with (lanes $B$ and $D$ ) reduction with $1 \% \beta$ mercaptoethanol. The position of the labeled proteins were deter-

mined by flurography with ${ }^{14} \mathrm{C}$-labeled collagen (rat tail tendon) as a molecular weight marker (28). The bands corresponding to processed procollagens are defined by the brackets. 


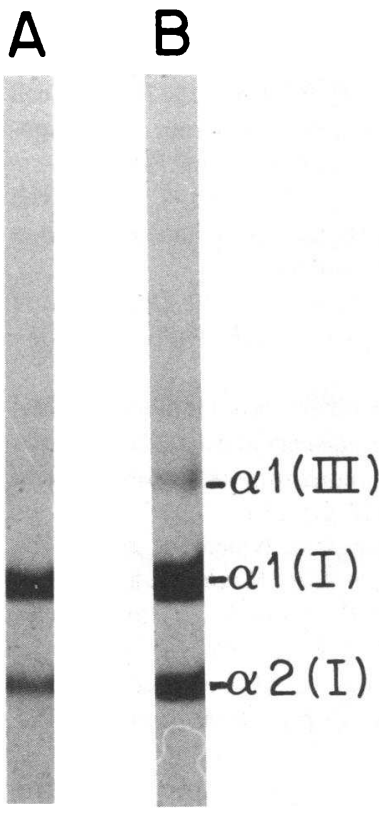

Figure 5. Medium proteins synthesized by cultured giant cell tumor stromal cells. Labeled medium proteins from cultures of giant cell tumors were pepsinized at $4^{\circ} \mathrm{C}$ and the proteins separated by SDS PAGE without (lane $A$ ) or with (lane $B$ ) interrupted reduction permitting separation of the $\alpha 1$ (I) or $\alpha 1$ (III) collagen chains.

the tumor. Tissue macrophages have been shown to demonstrate considerable variability in their reactivity with the monoclonal antibodies that recognize monocyte-macrophage-associated antigens, and to a great extent this pattern of reactivity is determined by the tissues in which these cells reside (37).

Burmester et al. (20) speculated that the tumor cells expressing monocyte-macrophage phenotype could represent a progenitor of the multinucleated giant cell present in the tumor. They noted, as did we, that cells expressing this phenotype did not proliferate or survive in culture, and that the proliferating cells were devoid of monocyte-macrophage or HLA class II antigens. If these mononuclear cells were in fact the precursor of tumor-associated giant cells, their failure to survive in culture could explain our inability to detect the large multinucleated giant cells after passage.

To further characterize the cells present in giant cell tumors, and to establish their relationship to cells of skeletal tissue origin, we examined the capacity of cells cultured from these tumors to increase cAMP levels when challenged with hormones that regulate skeletal tissue homeostasis. We had previously shown that cells cultured from giant cell tumors increase cAMP levels when incubated with PTH or PGE 2 (21-23). Using photoaffinitylabeling techniques we partially characterized the PTH receptor in these cells and demonstrated a similarity of the PTH-binding component to the PTH receptor in other target tissues (26). These initial studies were conducted on cells after passage, and because all of the multinucleated and many of the mononuclear cells did not persist after primary culture, in our present studies we specifically investigated hormone responses in cells in primary culture. We were particularly interested in determining the presence of responsiveness to $C T$, because responses to this hormone among bone cells is probably unique for osteoclasts. Chambers et al. (38) had previously reported that addition of CT to cells cultured from giant cell tumors induced morphological changes in the giant cells and decreased their ability to resorb devitalized bone. In the present study we were able to demonstrate CTinduced cAMP responses in cells in primary culture. Furthermore we demonstrated, using $\left[{ }^{125} \mathrm{I}\right]$ salmon CT autoradiography, that the multinucleated giant cells were the principle cell type expressing CT receptors. The disappearance of these cells in culture was accompanied by the loss of CT-induced cAMP responses. We were also able to identify a small population of mononuclear cells that specifically bound CT. These cells did not persist beyond the first passage, and it is possible that they represent precursors of the CT receptor-positive multinucleated cells. Our techniques did not permit simultaneous examination of the CT-positive mononuclear cells for the presence of macrophage-associated antigens. Thus, we were unable to establish the relationship of the CT-binding mononuclear cells to monocyte-macrophages. It is possible that these CT-binding mononuclear cells are related to the My-7-positive cells described by Horton et al. $(14,15)$ or the cells expressing the MO-U50 antigen described by Burmester et al. (20).

The failure to detect multinucleated giant cells after passage, as well as the absence of CT-responsive cells expressing monocyte-macrophage antigens in the proliferating cell population, strongly suggests that the latter cells (which likely represent the neoplastic cellular element of the tumor) are not the principle cellular precursor of the multinucleated giant cells. Further support for this concept is provided by the studies of Byers et al. (39), who injected cells cultured from giant cell tumors into nude mice. Tumor nodules developed in all animals and the tumor cells were morphologically indistinguishable from the stromal cells of the original tumor. No multinucleated cells were detected in these tumor growths, however. Furthermore, they defined a tumor-associated antigen by reacting autologous sera from two patients with cells derived from their own tumors. Using fluorescein-conjugated goat anti-human IgG as a second antibody they were able to demonstrate that $40 \%$ of the tumor stromal cells reacted with the sera, whereas none of the multinucleated cells were reactive. Nevertheless, these results as well as the results of other studies do not definitively establish the cell of origin for the multinucleated giant cell. These cells may in fact be heterogeneous, representing fusion products from different mononuclear cell types present in the tumor.

The presence of CT receptors in multinucleated cells present in giant cell tumors as well as the histological and histochemical features of these cells suggests that they are related to cells of osteoclast lineage. However, Aparisi et al. $(6,7)$ have suggested that the multinucleated cells present in these tumors have ultrastructural features that are distinct from true osteoclasts. Whether this reflects a different lineage for the tumor giant cells or the effects of factors or conditions present within these tumors remains uncertain. Horton et al. $(14,15)$ have generated monoclonal antibodies to cells from giant cell tumors and have identified several antibodies that appear to react principally with the multinucleated cells present in the tumor, as well as multinucleated cells in human fetal bone. These results suggest that the antibodies may indeed recognize antigens expressed on osteoclast-type giant cells. Reactivity of these antibodies with multinucleated cells present in synovium, however, raises questions concerning the specificity of these antibodies, because other investigators have shown that synovial giant cells express macrophage surface markers and are likely examples of so-called inflammatory polykaryons $(40)$. Horton et al. $(14,15)$ noted the absence of reactivity of the monoclonal antibodies with the tumor stromal cells, but detected binding with other mononuclear cells present in the tumor tissue. It is possible that these mononuclear cells represent the precursors of the multinucleated cells and may be analogous to the CT receptor-positive cells detected with our methods. 
The fibroblast-like morphology, the absence of monocytemacrophage-associated antigens, and the presence of receptors to PTH suggested the possible relationship of the cell which proliferates in culture to a connective tissue stromal cell. Incubation of the proliferating cells with $\left[{ }^{3} \mathrm{H}\right]$ proline demonstrated the capacity of these cells to incorporate label into several different high molecular weight proteins including products with mobility on electrophoresis and susceptibility to pepsin characteristic of types I and III collagen. Human macrophages in culture secrete fibronectin but do not produce detectible levels of types I or III collagen, $(41,42)$, thus providing further evidence that the proliferating cell is not phenotypically related to cells of monocyte-macrophage lineage. Although the pattern of collagen types in cells cultured from tumor tissue resembles that observed in dermal fibroblast cultures, the presence of several low molecular weight species suggests processing of the procollagens. The pattern of processing was highly reproducible in the cells cultured from different tumors and may reflect a distinctive mechanism for processing procollagens.

Unfortunately our studies do not establish the relationship of the proliferating cell to a specific connective tissue cell type. The presence of receptors for PTH is not unique to osteoblasts because we have shown comparable PTH binding and PTHinduced cAMP responses in dermal fibroblasts (26) and synovial fibroblasts (43). However, the consistent association of tumor stromal cells with cells expressing phenotypic features of osteoclasts suggests that the neoplastic cellular component of this tumor could be related to a cell of skeletal tissue origin which plays a role in the recruitment and formation of osteoclasts. It has been shown that cells related to osteoblasts in the presence of interleukin 1 or PTH have the capacity to stimulate isolated osteoclasts to resorb bone (44). In conclusion, these tumors may provide a good model for investigating the ontogeny and differentiation of skeletal tissue cells as well as a system for studying the mechanisms involved in the recruitment and regulation of the biological activity of cells of osteoclast lineage.

\section{Acknowledgments}

We thank Carolyn M. Rourke for technical assistance; Mark C. Gebhardt, M.D. and Henry J. Mankin, M.D. for providing tumor samples; Edward P. Amento, M.D. for assistance in evaluating cell surface markers; Stephen M. Krane, M.D. for general advice; and Michele Angelo for preparation of the manuscript.

This work was supported by the National Institutes of Health grant AM-03564.

\section{References}

1. Jaffe, H. L., L. Lichtenstein, and R. B. Portis. 1940. Giant cell tumor of bone. Its pathologic appearance, grading, supposed variants and treatment. Arch. Pathol. 30:993-1031.

2. Dahlin, D. C., R. E. Cupps, and E. W. Johnson, Jr. 1970. Giantcell tumor: a study of 195 cases. Cancer (Phila.). 25:1061-1070.

3. Goldenberg, R. R., C. J. Campbell, and M. Bonfiglio. 1970. Giantcell tumor of bone: an analysis of two hundred and eighteen cases. $J$. Bone Jt. Surg. Am. Vol. 52A:619-664.

4. Larsson, S.-E., R. Lorentzon, and L. Boquist. 1975. Giant-cell tumor of bone: a demographic, clinical, and histopathological study of all cases recorded in the Swedish Cancer Registry for the years 1958 through 1968. J. Bone Joint Surg. 57A:167-173.

5. McGrath, P. J. 1972. Giant-cell tumour of bone: an analysis of fifty-two cases. J. Bone Joint Surg. 54B:213-229.
6. Shifrin, L. Z. 1972. Giant cell tumor of bone. Clin. Orthop. Relat. Res. 82:59-66.

7. Aparisi, T., B. Arborgh, and J. L. E. Ericsson. 1977. Giant cell tumor of bone: detailed fine structural analysis of different cell components. Virchows Arch. A Pathol. Anat. Histopathol. 376:273-298.

8. Aparisi, T., B. Arborgh, and J. L. E. Ericsson. 1977. Giant cell tumor of bone: fine structural localization of acid phosphatase. Virchows Arch. A Pathol. Anat. Histopathol. 376:299-308.

9. Hanaoka, H., B. Friedman, and R. P. Mack. 1970. Ultrastructure and histogenesis of giant-cell tumor of bone. Cancer (Phila.). 25:14081423.

10. Jeffree, G. M., and C. H. G. Price. 1965. Bone tumors and their enzymes: a study of the phosphatases, non-specific esterases and betaglucuronidase of osteogenic and cartilaginous tumors, fibroblastic and giant-cell lesions. J. Bone Joint Surg. 47B:120-136.

11. Johnston, J. 1977. Giant cell tumor of bone. The role of the giant cell in orthopaedic pathology. Orthop. Clin. North Am. 8:751-770.

12. Steiner, G. C., L. Ghosh, and H. D. Dorfman. 1972. Ultrastructure of giant cell tumors of bone. Hum. Pathol. 3:569-586.

13. Schajowicz, F. 1961. Giant cell tumors of bone (osteoclastoma). A pathological and histochemical study. J. Bone Joint Surg. Am. Vol. 43A:1-29.

14. Horton, M. A., J. A. S. Pringle, and T. J. Chambers. 1985. Identification of human osteoclasts with monoclonal antibodies. $N$. Engl. J. Med. 312:923-924.

15. Horton, M. A., D. Lewis, K. McNulty, J. A. S. Pringle, T. J. Chambers. 1985. Monoclonal antibodies to osteoclastomas (giant cell bone tumors): definition of osteoclast-specific cellular antigens. Cancer Res. 45:5663-5669.

16. Kahn, A. J., and D. J. Simmons. 1975. Investigation of cell lineage in bone using a chimaera of chick and quail embryonic tissue. Nature (Lond.). 258:325-329.

17. Fischman, D. A., and E. D. Hay. 1962. Origin of osteoclasts from mononuclear leukocytes in regenerating newt limbs. Anat. Rec. 143: 329-341.

18. Jee, W. S. S., and P. D. Nolan. 1963. Origin of osteoclasts from the fusion of phagocytes. Nature (Lond.). 200:225-227.

19. Horton, M. A., E. F. Rimmer, D. Lewis, J. A. S. Pringle, K. Fuller, and T. J. Chambers. 1984. Cell surface characterization of the human osteoclast: phenotypic relationship to other bone marrow-derived cell types. J. Pathol. 144:281-294.

20. Burmester, G. R., R. J. Winchester, A. Dimitriu-Bona, M. Klein, G. Steiner, and H. A. Sissons. 1983. Delineation of four cell types comprising the giant cell tumor of bone. Expression of Ia and monocytemacrophage lineage antigens. J. Clin. Invest. 71:1633-1648.

21. Goldring, S. R., H. J. Mankin, M. Roelke, E. P. Amento, A. K. Bhan, C. M. Rourke, and S. M. Krane. 1984. Characterization of cells cultured from human giant cell tumor of bone (GT). Calcif. Tiss. Int. 36:460. (Abstr.)

22. Goldring, S. R., J.-M. Dayer, R. G. G. Russell, H. J. Mankin, and S. M. Krane. 1977. Cells cultured from human giant cell tumors of bone respond to parathyroid hormone. Calcif. Tiss. Res. 22(Suppl.): 269-274.

23. Goldring, S. R., J.-M. Dayer, R. G. G. Russell, H. J. Mankin, and S. M. Krane. 1978. Response to hormones of cells cultured from human giant cell tumors of bone. J. Clin. Endocrinol. \& Metab. 46:425433.

24. Goldring, S. R., J. E. Mahaffey, M. Rosenblatt, J.-M. Dayer, J. T. Potts, Jr., and S. M. Krane. 1979. Parathyroid hormone inhibitors: comparison of biological activity in bone (and skin)-derived tissue. $J$. Clin. Endocrinol. \& Metab. 48:655-659.

25. Goldring, S. R., M. S. Roelke, F. R. Bringhurst, and M. Rosenblatt. 1985. Differential effects of parathyroid hormone responsive cultured human cells on biological activity of parathyroid hormone and parathyroid hormone inhibitory analogues. Biochemistry 24:513-518.

26. Goldring, S. R., G. A. Tyler, S. M. Krane, J. T. Potts, Jr., and M. Rosenblatt. 1984. Photoaffinity labeling of parathyroid hormone re- 
ceptors: comparison of receptors across species and target tissues and after desensitization to hormone. Biochemistry 23:498-502.

27. Goldring, S. R., J.-M. Dayer, and S. M. Krane. 1979. Regulation of hormone-induced cyclic AMP response to parathyroid hormone and prostaglandin $\mathrm{E}_{2}$ in cells. Calcif. Tiss. Int. 29:193-200.

28. Amento, E. P., A. K. Bhan, K. G. McCullagh, and S. M. Krane. 1985. Influences of gamma interferon on synovial fibroblastlike cells. Ia induction and inhibition of collagen synthesis. J. Clin. Invest. 76:837848.

29. Hunter, W. M., and F. C. Greenwood. 1962. Preparation of iodine131-labelled human growth hormone of high specific activity. Nature (Lond.). 194:494-496.

30. Hull, R. N., W. R. Cherry, and G. W. Weaver. 1976. The origin and characteristics of a pig kidney cell strain, LLC-PK $_{1}$. In Vitro 12: 670-677.

31. Bonner, W. M., and R. A. Laskey. 1974. A film detection method for tritium-labelled proteins and nucleic acids in polyacrylamide gels. Eur. J. Biochem. 46:83-88.

32. Goldring, S. R., A. L. Schiller, H. J. Mankin, J.-M. Dayer, and S. M. Krane. 1986. Characterization of cells from human giant cell tumors of bone. Clin. Orthop. Relat. Res. 204:59-75.

33. Goldring, S. R., J.-M. Dayer, D. A. Ausiello, and S. M. Krane. 1978. A cell strain cultured from porcine kidney increases cyclic AMP content upon exposure to calcitonin or vasopressin. Biochem. Biophys. Res. Commun. 83:434-440.

34. Nicholson, G. C., J. M. Moseley, P. M. Sexton, F. A. O. Mendelsohn, and T. J. Martin. 1986. Abundant calcitonin receptors in isolated rat osteoclasts. Biochemical and autoradiographic characterization. $J$. Clin. Invest. 78:355-360.

35. Wood, G. W., J. R. Neff, K. A. Gollahon, and W. K. Gourley. 1978. Macrophages in giant cell tumours of bone. J. Pathol. 125:53-58.
36. Bhan, A. K., and C. L. DesMarais. 1983. Immunohistologic characterization of major histocompatibility antigens and inflammatory cellular infiltrate in human breast cancer. J. Nat. Cancer Inst. 71:507516.

37. Franklin, W. A., D. Y. Mason, K. Pulford, B. Falini, E. Bliss, K. C. Gatter, H. Stein, L. C. Clarke, and J. O'D. McGee. 1986. Immunohistological analysis of human mononuclear phagocytes and dendritic cells by using monoclonal antibodies. Lab. Invest. 54:322-335.

38. Chambers, T. J., K. Fuller, and P. M. J. McSheehy. 1985. The effects of calcium regulating hormones on bone resorption by isolated human osteoclastoma cells. J. Pathol. 145:297-305.

39. Byers, V. S., A. S. Levin, J. O. Johnston, and A. J. Hackett. 1975. Quantitative immunofluorescence studies of the tumor antigen-bearing cell in giant cell tumor of bone and osteogenic sarcoma. Cancer Res. 35: 2520-2528.

40. Poulter, I. W., O. Duke, S. Hobbs, G. Janossy, and G. Panayi. 1982. Histochemical discrimination of HLA-DR positive cell populations in the normal and arthritic synovial lining. Clin. Exp. Immunol. 48:381388.

41. Villiger, B., D. G. Kelley, W. Engleman, C. Kuhn, III, and J. A. McDonald. 1981. Human alveolar macrophage fibronectin: synthesis, secretion, and ultrastructural localization during gelatin-coated latex particle binding. J. Cell Biol. 90:711-720.

42. Alitalo, K., T. Hovi, and A. Vaheri. 1980. Fibronectin is produced by human macrophages. J. Exp. Med. 151:602-613.

43. Goldring, S. R., J.-M. Dayer, and S. M. Krane. 1984. Rheumatoid synovial cell hormone responses modulated by cell-cell interactions. Inflammation 8:107-121.

44. Thomson, B. M., J. Saklatvala, and T. J. Chambers. 1986. Osteoblasts mediate interleukin 1 stimulation of bone resorption by rat osteoclasts. J. Exp. Med. 164:104-112. 